\title{
ДОСЛІДЖЕННЯ СОЦІАЛЬНОÏ КОМПЕТЕНТНОСТІ У ШКОЛЯРІВ ІЗ ПОРУШЕННЯМИ ІНТЕЛЕКТУАЛЬНОГО РОЗВИТКУ
}

Трансформації, що відбуваються в сучасному суспільстві, охоплюють усі сфрери життя й освіта не є виключенням. Численні нововведення, які відбуваються в освіті, зокрема запровадження Концепції Нової української школи, державних стандартів початкової та базової середньої освіти, націлені на створення компетентної особистості, яка в результаті навчання має бути не лише озброєна академічними знаннями, а й вміти застосовувати набуті знання, уміння, навички в повсякденному житті та бути здатною до соціальної взаємодії.

Мета статmі полягає у визначенні стану сформованості соціальної компетентності в молодших школярів та молодших підлітків із нормотиповим та порушеним інтелектуальним розвитком.

У статті теоретично обгрунтовано, що формування соціальної компетентності є необхідною умовою для ефективної соціальної взаємодії в сучасному суспільстві. Уточнено поняття соціальної компетентності, акцентовано увагу на тому, що вона є складником ключових компетентностей, охоплює різні внутрішні фрактори і зовнішню поведінку, впливає на здатність та якість соціальної взаємодії тощо. Діагностовано стан сформованості соціальної компетентності в молодших школярів та підлітків із порушеннями інтелектуального розвитку. Зокрема, зазначено, що порушення соціальної адаптації у дітей з особливими освітніми потребами викликає складнощі для самовираження і потребує допомоги для їх адаптації в соціальному середовищі.

Представлено результати дослідження сорормованості соціальної компетентності молодших школярів та молодших підлітків із порушеннями інтелектуального розвитку та їх однолітків із нормотиповим розвитком. З'ясовано відмінності складників соціальної компетентності у двох груп школярів та обгрунтовано, що для фрормування та розвитку ключових компетентностей, зокрема соціальної, необхідне організоване навчання, в процесі якого учні можуть як засвоювати різні способи спілкування, так і відпрацьовувати їх на практиці, що своєю чергою дає змогу учневі бути компетентним у різних сферах життєдіяльності, займати соціально активну позицію в суспільстві, вміти вибудовувати моделі соціальної взаємодії та адекватно реагувати на зміни, які постійно відбуваються в повсякденному житті.

Визначено перспективу дослідження, що полягатиме в пошуку і науковому обґрунтуванні змісту, методів і засобів навчання, які дадуть змогу ефективно підвищити рівень соціальної компетентності учнів із порушеннями інтелектуального розвитку.

Ключові слова: освіта, спеціальна педагогіка, компетентнісний підхід, діти з особливими освітніми потребами.

Постановка проблеми. Останнім часом реформи, які відбуваються в освітній галузі, зорієнтовані на рівень світових стандартів. У державних стандартах початкової та базової середньої освіти, які визначають вимоги до обов'язкових результатів навчання здобувачів освіти, зокрема, зазначено, що мета освіти полягає в розвитку природних здібностей учнів, їхніх інтересів та обдарувань, а також формування компетентностей які $€$ необхідними для їх соціалізації, громадянської активності, свідомого вибору подальшого життєвого шляху та самореалізації [1]. На думку G. Cartledge, соціальна компетентність - це умова оволодіння соціальними, емоційними та інтелектуальними навичками та поведінкою, які є необхідними для досягнення успіху як члена суспільства. У своєму дослідженні авторка зазначає, що соціальна компетентність дитини залежить від низки фракторів, включаючи соціальні навички дитини, соціальну обізнаність і впевненість у собі [6].

Соціальна компетентність $€$ частиною складної системи, що охоплює різні внутрішні фрактори і зовнішню поведінку, що впливає на здатність та якість соціальної взаємодії [3, с. 217].

Таким чином, пріоритетним завданням закладу освіти стає побудова такого освітнього процесу, щоб учні отримували не лише знання, а й вміння та навички використовувати їх у реальному житті [2].

Як зазначає Н. Ярмола, особливої актуальності це питання набуває щодо навчання дітей ыз порушеннями інтелектуального розвитку. Вчена наголошує, що порушення соціальної адаптації в таких дітей викликає складнощі самоідентифікації і потребує допомоги в адаптації в соціальному середовищі. 
Отже, процес інтеграції в суспільство дітей ыз порушеннями інтелектуального розвитку (далі ПІР) має передбачати систему психолого-педагогічного та соціально-реабілітаційного супроводу, спрямованого на створення ефективних умов соціальної адаптації дітей, розвиток соціальної компетентності та ін.

Аналіз останніх досліджень і публікацій. Теоретичний аналіз джерел свідчить, що у спеціальній педагогічній та психологічній літературі питання соціалізації дітей із порушеннями інтелектуального розвитку займає важливе місце: питання стосовно характеристик, сутності та змісту, соціальної адаптації дітей із ПІР досліджувались І. Бехом, Л. Виготським, І. Лубовським, В. Синьовим та ін.; психолого-педагогічні основи соціалізації дітей 3 інтелектуальними порушеннями розглядалися В роботах В. Липи, Г. Мерсіянової, І. Татьянчікової, Я. Утьосова; професійно-трудову соціалізацію учнів із порушеннями інтелектуального розвитку досліджували Ю. Бистровою, В. Бондарем, К. Рейдою, О. Хохліною та ін.; питанням міжособистісних відносин учнів із ПІР приділяли увагу Т. Кузьміна, К. Лебединська, Л. Руденко та ін. Вивченню питання соціальної компетентності дітей із порушеннями інтелектуального розвитку свої праці присвятили О. Борисова, О. Гребеннікова, І. Ляпіна, Д. Нечаєва, П. Омарова, Я. Утьосов, І. Шелехов, Н. Ярмола та ін.

Мета статті полягає у визначенні стану сформованості соціальної компетентності в молодших школярів та молодших підлітків із нормотиповим та порушеним розвитком.

Виклад основного матеріалу. Розглядаючи освітній процес як такий, що передбачає не лише академічне навчання, а й соціальний розвиток, серед ключових компетентностей учнів із порушеннями інтелектуального розвитку важливе місце посідає соціальна компетентність.

До змісту соціальної компетентності включено соціальні навички, здатність взаємодіяти з іншими людьми, навички взаєморозуміння, вміння встановлювати нові контакти, мобільність (у різних навчальних та соціальних умовах), здатність уникати конфліктних ситуацій та знаходити вихід із них, уміння визначати особисті ролі в соціумі.

3 огляду на це для перевірки рівня сформованості соціальної компетентності учнів із порушеннями інтелектуального розвитку були використанні такі методики: «Вивчення здатності визначати емоційні стани дітей у шкільній ситуації» (Л. Фатіхова); «Я і школа» (Л. Фатіхова); «Комунікативний лист» (Л. Шипіцина).

Розглянемо отримані результати.

Застосована методика «Вивчення здатності визначати емоційні стани дітей у шкільній ситуації» (Л. Фатіхова) спрямована на визна- чення вміння дитини орієнтуватися в емоційних станах учасників освітнього процесу, розуміння протиріччя в емоційних станах учасників шкільної ситуації. Методика передбачала шість сюжетних малюнків, які зображували різні шкільні ситуації. У процесі дослідження експериментатор показував учню малюнок із зображенням конфрліктної шкільної ситуації, в якій один з учасників відчуває неадекватний цій ситуації емоційний стан, супроводжуючи показ малюнка розповіддю.

Сюжетні малюнки учням пропонували розглядати по черзі. Після показу малюнка експериментатор просив учня визначити, чи правильно реагує персонаж на ситуацію і що насправді він має відчувати.

Бали за виконану роботу ставилися окремо по кожній ситуації, за підсумком суми всіх балів (максимально 24 бали) отриманих по кожному сюжетному малюнку визначався ступінь розуміння учнем емоційних станів учасників освітнього процесу, їх відмінності та ситуації, в яких вони виникають: 21-24 бали - високий рівень; 17-20 балів - оптимальний рівень; 13-16 балів - достатній рівень; 9-12 балів - знижений рівень; 5-8 балів - низький рівень; 0-4 балів - критичний рівень.

Таблиця 1

Оцінка рівня сформованості вміння орієнтуватися в емоційних станах учнів із порушеним інтелектом та нормотиповим розвитком

\begin{tabular}{|l|c|c|c|c|}
\hline \multirow{2}{*}{\multicolumn{1}{|c|}{ Рівні }} & \multicolumn{2}{|c|}{ Молодші школярі } & \multicolumn{2}{c|}{ Молодші підлітки } \\
\cline { 2 - 5 } & ПІР & НP & ПІР & НР \\
\hline високий & $0 \%$ & $97 \%$ & $0 \%$ & $95 \%$ \\
\hline оптимальний & $0 \%$ & $3 \%$ & $0 \%$ & $5 \%$ \\
\hline достатній & $0 \%$ & $0 \%$ & $5 \%$ & $0 \%$ \\
\hline знижений & $4 \%$ & $0 \%$ & $21 \%$ & $0 \%$ \\
\hline низький & $33 \%$ & $0 \%$ & $27 \%$ & $0 \%$ \\
\hline критичний & $63 \%$ & $0 \%$ & $47 \%$ & $0 \%$ \\
\hline
\end{tabular}

Аналіз отриманих результатів дає змогу стверджувати, що у школярів із нормотиповим розвитком не виникало проблем із визначенням емоційних станів.

Втім для дітей із порушеннями інтелекту, з огляду на те, що для них характерними $є$ невміння чітко розрізняти почуття та емоції, обмежений діапазон переживань та ін., зрозуміти зображені емоції на малюнках виявилося складним завданням.

Розглядаючи малюнки, діти звертали увагу не на емоції, а на поведінку зображених персонажів. Запитання експериментатора доволі часто ігнорувалися, бо деякі діти починали розповідати власний варіант розвитку подій, спираючись на свій досвід у схожих ситуаціях. У дітей із ПІР спостерігалися неадекватні емоційні реакції.

Водночас варто зазначити, що в дітей із порушеннями інтелектуального розвитку термін вико- 
нання завдання був набагато довшим, ніж у нормотипових дітей. Багато дітей із ПІР взагалі не змогли впоратись із завданням після усіх видів допомоги (63\% молодших школярів і $47 \%$ молодших підлітків).

Частина учнів із порушеннями інтелектуального розвитку змогла впоратися із завданням після отримання всіх видів допомоги (33\% молодших школярів та $27 \%$ молодших підлітків).

Зрозуміти невідповідність емоційного стану характеру ситуації змогли $21 \%$ молодших підлітків із ПІР і лише 4\% молодших школярів із ПІР, але навіть після отримання допомоги з боку експериментатора учні не змогли пояснити причини емоційного стану.

Серед молодших підлітків із ПІР 5\% зрозуміли невідповідність емоційного стану характеру ситуації та змогли пояснити причини цього емоційного стану після отримання всіх видів допомоги.

Аналіз результатів за методикою «Вивчення здатності визначати емоційні стани дітей в шкільній ситуації» засвідчив, що рівень вмінь орієнтуватися в емоційних станах у школярів із порушеннями інтелектуального розвитку значно нижчий, ніж у нормотипових однолітків. Таку різницю зумовлюють особливості емоційно-вольової сфери дітей із ПІР, яка характеризується недорозвитком та нестійкістю емоцій, відсутністю відтінків переживань.

Методика «Я і школа» (Л. Фатіхова) була спрямована на вивчення здатності усвідомлення дитиною шкільного життя, рівня сформованості моральної свідомості, навичок взаєморозуміння. Матеріал методики містив чотири сюжетні малюнки, на яких було зображено шкільні ситуації. Розглянувши кожний малюнок окремо, учень мав відповісти на питання експериментатора стосовно зображених ситуацій.

Під час відповідей на питання стосовно поведінки персонажів складнощів не виникало, а питання щодо почуттів для дітей із порушеннями інтелектуального розвитку видалися складними.

Таблиця 2

Оцінка рівня сформованості здатності усвідомлення шкільного життя, рівня сформованості моральної свідомості, навичок взаєморозуміння учнів із порушеним інтелектом та нормотиповим розвитком

\begin{tabular}{|l|c|c|c|c|}
\hline \multirow{2}{*}{\multicolumn{1}{c|}{ Рівні }} & \multicolumn{2}{|c|}{ Молодші школярі } & \multicolumn{2}{c|}{ Молодші підлітки } \\
\cline { 2 - 5 } & ПІР & НP & ПІР & НP \\
\hline оптимальний & $3 \%$ & $92 \%$ & $9 \%$ & $98 \%$ \\
\hline достатній & $11 \%$ & $7 \%$ & $19 \%$ & $2 \%$ \\
\hline знижений & $32 \%$ & $1 \%$ & $34 \%$ & 0 \\
\hline низький & $54 \%$ & 0 & $38 \%$ & 0 \\
\hline
\end{tabular}

Результати, отримані під час методики, були такими.
Серед учнів із порушеннями інтелектуального розвитку $54 \%$ молодших школярів та $38 \%$ молодших підлітків не змогли виконати завдання після надання всіх видів допомоги з боку дорослого.

Майже однакова кількість дітей обох вікових категорій із порушеннями інтелектуального розвитку не усвідомлювали повністю запропоновані ситуації шкільного життя. Вони розуміли правила, зображені на малюнках, але не розуміли відповідність або невідповідність вчинків персонажів на малюнку правилам. Зазвичай не вважали поганими вчинки персонажів. А з визначенням емоційних станів у дітей виникали значні проблеми.

Відсоток дітей, які розуміли зображену на сюжетному малюнку ситуацію, знали передбачене змістом сюжету правило, розуміли відповідність або невідповідність вчинків персонажів малюнку, правильно визначали емоційні стани персонажів малюнку, але не могли змоделювати морально правильну поведінку, був таким: молодших школярів із ПІР - 11\%, молодших підлітків із ПІР - 19\%.

У дітей із нормотиповим розвитком виконання завдань методики не викликали труднощів. Майже всі діти повною мірою усвідомлювали ситуацію шкільного життя, знали і приймали правила, передбачені змістом сюжетних малюнків, розуміли відповідність або невідповідність поведінки персонажів ситуацій та пропонували власний варіант морально правильної поведінки. Серед дітей із порушенням інтелектуального розвитку такі діти теж були: молодші школярі - 3\%, молодші підлітки - 9\%.

Методика «Комунікативний лист» (Л. Шипіцина), за допомогою якої визначався стан мовного компоненту соціальної компетентності, передбачала в процесі спостереження за повсякденною діяльністю учня, в ситуації вільного або організованого спілкування, фріксувати уміння дитини вітатися та прощатися, звертатися до співрозмовника, відповідати та ставить запитання, виражати прохання, не перебивати.

Кількісна оцінка реєстрованих параметрів здійснювалась таким чином: 1 бал - достатній рівень сформованості уміння (навички); 0,5 бала середній рівень; 0 балів - низький рівень.

Таблиця 3

Оцінка рівня сформованості мовного компонента соціальної компетентності учнів із порушеним інтелектом та нормотиповим розвитком

\begin{tabular}{|l|c|c|c|c|}
\hline \multirow{2}{*}{ Рівні } & \multicolumn{2}{|c|}{ Молодші школярі } & \multicolumn{2}{c|}{ Молодші підлітки } \\
\cline { 2 - 5 } & ПІР & НP & ПІР & НP \\
\hline низький & $52 \%$ & $0 \%$ & $31 \%$ & $0 \%$ \\
\hline середній & $44 \%$ & $4 \%$ & $55 \%$ & $12 \%$ \\
\hline достатній & $4 \%$ & $96 \%$ & $14 \%$ & $88 \%$ \\
\hline
\end{tabular}




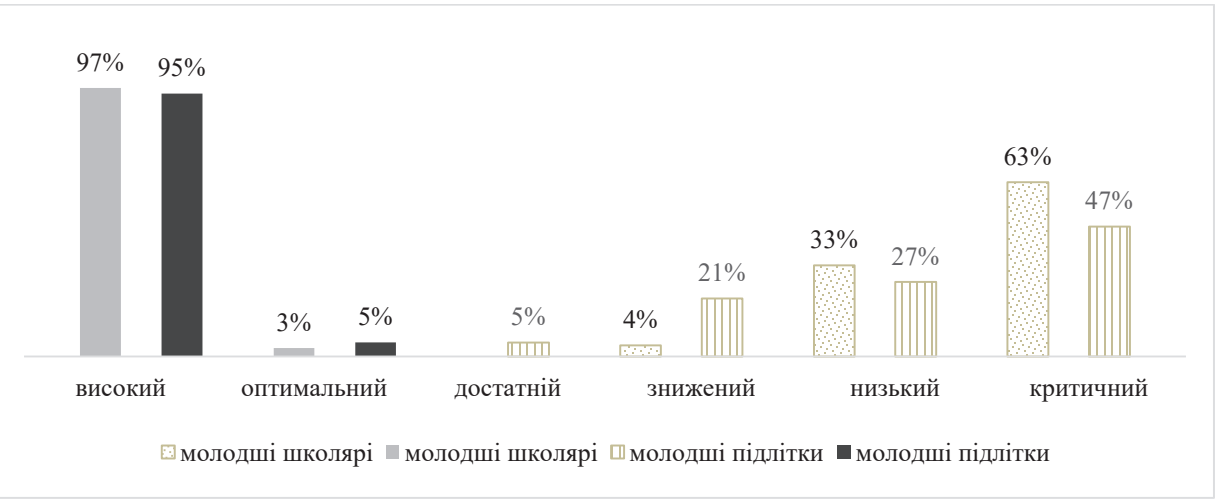

Рис. 1. Порівняння рівня сформованості вміння орієнтуватися в емоційних станах учасників освітнього процесу учнів із порушеним інтелектом та нормотиповим розвитком

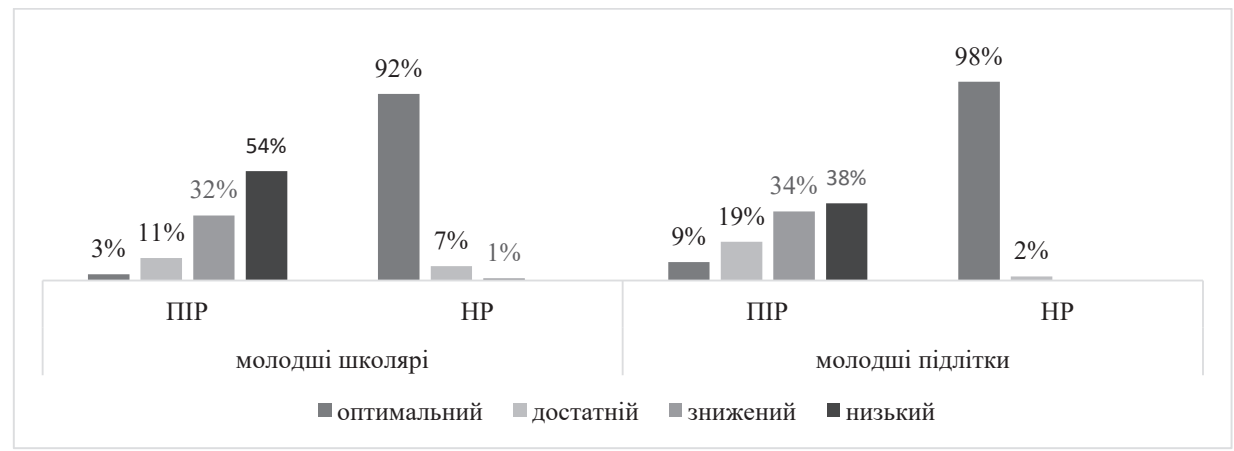

Рис. 2. Порівняння рівня сформованості здатності усвідомлення шкільного життя, рівня сформованості моральної свідомості, навичок взаєморозуміння учнів із порушеним інтелектом та нормотиповим розвитком

За отриманими результатами методики можна говорити, що комунікативні навички учнів із порушеннями інтелектуального розвитку мають певні особливості, які зумовлені ступнем інтелектуального розвитку дитини, її індивідуально-психологічними особливостями, соціальним оточенням та ін.

Дані, які наведені у таблиці 3, вказують на те, що $52 \%$ молодших школярів та $31 \%$ молодших підлітків із порушеннями інтелектуального розвитку продемонстрували низький рівень розвитку мовленнєвого спілкування.

Із загальної кількості учнів, молодших школярів із порушеннями інтелектуального розвитку та молодших підлітків із ПІР, відповідно, 44\% і 55\% отримали ту кількість балів, яка свідчить про середній рівень розвитку мовленнєвого спілкування. Якісний аналіз свідчить, що ці діти майже завжди віталися та прощалися з педагогами і відвідувачами закладу (втім молодшим школярам іноді потрібно було про це нагадувати), у спілкуванні з однолітками ставили питання вкрай рідко, але робили пропозиції щодо спільної діяльності. Одні учні проявляли надмірну імпульсивність під час спілкування, постійно перебивали співрозмовника, інші під час бесіди починали займатися своїми справами, втрачали інтерес до спілкування. у 14\% молодших підлітків із порушеннями інтелектуального розвитку та в 4\% молодших школярів виявлено достатній рівень розвитку мовленнєвого спілкування. Ці діти без нагадувань віталися та прощалися з педагогами та відвідувачами закладу, дотримувалися соціально прийнятних норм у спілкуванні, могли поставити питання та дати зрозумілу відповідь.

Отже, результати дослідження свідчать про необхідність вдосконалення комунікативних навичок у дітей із порушеннями інтелектуального розвитку як одного з провідних компонентів соціальної компетентності. Для їх формування та розвитку необхідне організоване навчання, в процесі якого учні можуть як засвоювати різні способи спілкування, так і відпрацьовувати їх на практиці, щоб стати компетентними в різних сфрерах життєдіяльності, бути соціально активними членами суспільства, вміти будувати відносини та адекватно реагувати на зміни.

Висновки і пропозиції. Таким чином, низький рівень сорормованості соціальної компетентності в учнів із порушеннями інтелектуального розвитку не лише спричиняє поведінкові проблеми, але й викликає серйозні перешкоди в академічному, соціальному та емоційному розвитку дітей i, як наслідок, негативно впливає на їх адаптацію до дорослого життя. 


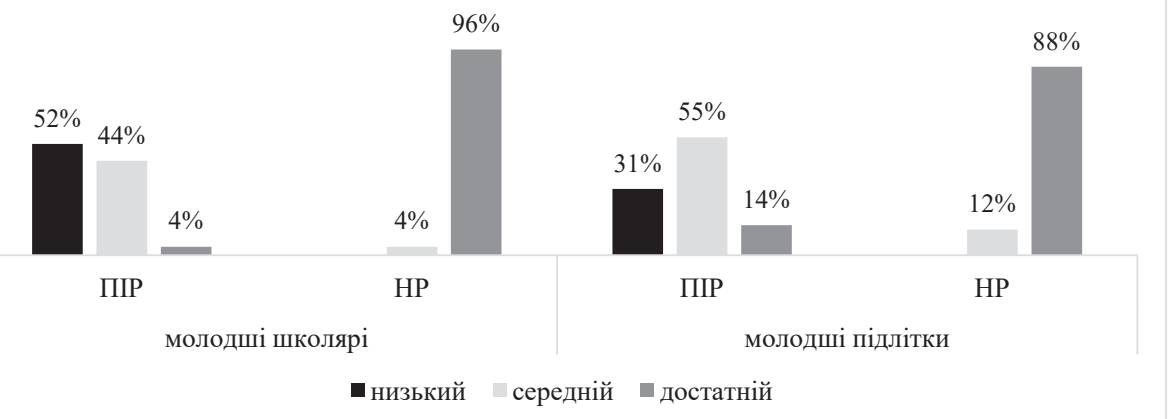

Рис. 3. Порівняння рівнів сформованості мовного компонента соціальної компетентності учнів із порушеним інтелектом та нормотиповим розвитком

Отже, продовження дослідження може полягати в пошуку і науковому обґрунтуванні змісту, методів і засобів навчання фрормування соціальної компетентності учнів із порушеннями інтелектуального розвитку.

\section{Список використаної літератури:}

1. Державні стандарти URL: https://mon.gov.ua/ ua/osvita/zagalna-serednya-osvita/derzhavnistandarti (дата звернення 12.04.2021)

2. Концепція «Нова українська школа» (Розпорядження Кабінету Міністрів від 14 грудня 2016 р. No 988-р «Про схвалення Концепції реалізації державної політики у сфрері реформування загальної середньої освіти «Нова українська школа» на період до 2029 року»). URL: http://www.mon.gov.ua/

3. Тороп К.С. Компетентнісний підхід в освіті дітей $з$ порушеннями інтелектуального роз- витку. Scientific research of the XXI century. Volume 1 : collective monograph / Compiled by V. Shpak; Chairman of the Editorial Board S. Tabachnikov. Sherman Oaks, Los Angeles : GS publishing service, 2021. 430 p. DOI : 10.51587/9781-7364-13302-2021-001

4. Фатихова Л.Ф. Диагностический комплекс для психолого-педагогического обследования детей с интеллектуальными нарушениями. Уфа : ИЦ Уфимского филиала ГОУ ВПО «МГГУ им. М.А. Шолохова», 2011. 80 с.; 65 карт.

5. Ярмола Н. Формування соціальної компетентності дітей з інтелектуальними порушеннями. Освіта осіб з особливими потребами: виклики сьогодення. Київ : Наша друкарня, 2020. С. 71-76.

6. Cartledge, Gwendolyn, et al.Teaching Social Skills to Children.Circle Pines, MN: American Guidance Service, 2002. URL: http://www.healthofchildren.com/ S/Social-Competence.html

\section{Torop K. Research of social competence in schoolchildren with intellectual disabilities}

Transformations that are happening today in modern society, concern all spheres of life, education is no exception, it has a special role. The concept of the New Ukrainian School, the state standards of primary and basic secondary education are focused on the creation of a competent person, the result of education should not only be armed with academic knowledge, but also be able to apply the knowledge, abilities, skills in everyday life and be capable of social interaction.

The aim of the article is to determine the state of formation of social competence of junior schoolchildren and young teenagers with normotypic and disabled development. The article theoretically substantiates that the formation of social competence is a necessary condition for effective social interaction in modern society. The notion of social competence is specified, the attention is focused on the fact that it is a part of a complex system and covers various internal factors and external behavior, influences ability and quality of social cooperation. The state of formation of social competence of younger schoolchildren and teenagers with intellectual disabilities is diagnosed. It is pointed out that impaired social adaptation in children with special educational needs causes difficulties for self-expression and needs help for their adaptation in the social environment.

The article presents the results of the research of the formation of social competence of junior schoolchildren and young teenagers with intellectual disabilities and their normotypic peers. The differences in the components of social competence in two groups of schoolchildren were revealed. It was substantiated that in order to form and develop key competences, including social competence, it is necessary to provide an organized teaching during which students can both master different ways of communication and practice them in practice in order to become competent in different spheres of life activities, be a socially active member of society, be able to build relationships with social partners and adequately respond to changes that constantly occur in everyday life.

Determined the research perspective, which will consist of the search and scientific substantiation of the content, methods and means of education, allowing to effectively raise the level of social competence of students with intellectual developmental disabilities.

Key words: education, special pedagogy, competency-based approach, children with special educational needs. 